\title{
Contents of mineral elements in Finnish cereal straw
}

\author{
ANTTI JAAKKOLA ${ }^{1)}$, JORMA SYVÄLAHTI ${ }^{2)}$ and ESKO SAARI ${ }^{3)}$ \\ 1) Department of Agricultural Chemistry and Physics, Agricultural Research \\ Centre, 31600 JOKIOINEN \\ 2) Kemira Co., Malminkatu 30, 00100 HELSINKI 10 \\ 3) Kemira Co., Research Laboratory, P.O. Box 171, 90101 OULU 10
}

Abstract. Straw samples were collected in three consecutive years from 6 spring wheat, 26 barley and 9 oat plots fertilized normally. The plots were situated throughout Finland. P, K, Ca, Mg, Mn, Cu, $\mathrm{Zn}, \mathrm{B}$, $\mathrm{Mo}$, $\mathrm{Se}$ and $\mathrm{Cd}$ as well as in a more limited material $\mathrm{Co}, \mathrm{Cr}, \mathrm{Ni}$ and $\mathrm{Pb}$ were determined. The contents were in the range of contents published abroad under different conditions. Applying a salt mixture containing various elements in the first year did not in general markedly raise their contents in straw.

The samples were also taken from 6 field experiments where the effects of applying different elements in salt mixtures as well as that of the usual NPK fertilization on the mineral element composition of grain and straw were studied. NPK fertilizer did not change the composition markedly. Neither did it the direct application of elements to the soil.

\section{Introduction}

The content of mineral elements in straw is of importance, among other things, in its use as animal feed. In addition, nutrients are returned to the soil when the straw is ploughed in.

In order to learn about the mineral element contents of straw, samples collected during the Study on Mineral Elements in Finnish Soils and Plants (published in Acta Agric. Scand. Suppl. 20, 1978) were analyzed.

\section{Material and methods}

The straw samples were collected during the years 1974-76. There were two series of trials from which the straw samples were taken. One consisted of plot pairs whose performance is reported in detail by JAAKKOLA and VOGT (1978) and by VOGT and JAAKKOLA (1978). The other series consisted of the five-treatment four-replication field experiments reported by SYVÄLAHTI and KORKMAN (1978).

Only the straw samples taken from selected trials were analyzed. The 
selection was made from among those trials where the same crop was grown during all three experimental years. Spring wheat, barley and oat straw was included in the material. A brief description of the selected samples is given below.

\section{Plot pairs}

The spring wheat straw samples were collected from 6 plot pairs. These were situated at the South-West Finland Experimental Station, Mietoinen (2), at the Kymenlaakso Experimental Station, Anjalankoski (2) and at a private farm, Hausjärvi (2). All the plots were on mineral soils.

The samples of barley straw were taken from 26 plot pairs: the Kymenlaakso Experimental Station (1), the Central Finland Experimental Station, Laukaa (3), the Central-Pohjanmaa Experimental Station, Toholampi (5), the Kainuu Experimental Station, Vaala (5), the Karjala Experimental Station, Tohmajärvi (8) and from private farms in Utajärvi (2) and Vaala (2). Both mineral and organogenic soils were represented.

The oat straw was taken from 9 plot pairs situated at the Kymenlaakso Experimental Station (1), the Central-Finland Experimental Station (1), the Karjala Experimental Station (3) and from two private farms in Pihtipudas (4). Both mineral and organogenic soils were included.

The plot pairs were cultivated and fertilized normally with NPK during the experimental years 1974-76. At the beginning a mixture of salts containing various nutritive and harmful elements was applied to one of the plots in each pair. The compounds used and the application rates of the various elements were:

\begin{tabular}{|c|c|c|c|c|c|c|c|}
\hline Magnesium sulphate & $\mathrm{Mg}$ & & $\mathrm{kg} / \mathrm{ha}$ & Lead nitrate & $\mathrm{Pb}$ & 0.35 & $\mathrm{~kg} / \mathrm{ha}$ \\
\hline Copper sulphate & $\mathrm{Cu}$ & 12.5 & $"$ & Sodium arsenate & As & 0.45 & \\
\hline Ferrous sulphate & $\mathrm{Fe}$ & 10 & $"$ & Cadmium nitrate & $\mathrm{Cd}$ & 0.17 & ', \\
\hline Manganous sulphate & $\mathrm{Mn}$ & 13 & " & um fluoride & $\mathrm{F}$ & 0.13 & \\
\hline Zinc sulphate & $\mathrm{Zn}$ & 1.75 & $"$ & Sodium iodide & I & 0.84 & "' \\
\hline ium borate & B & 2.1 & $"$ & Mercuric nitrate & $\mathrm{Hg}$ & 0.17 & \\
\hline dium molybdate & Mo & 0.39 & " & Sodium selenite & $\mathrm{Se}^{\circ}$ & 0.21 & \\
\hline chromate & $\mathrm{Cr}$ & 0.13 & $"$ & Stannous sulphate & $\mathrm{Sn}$ & 0.16 & \\
\hline obalt sulphate & Co & 0.21 & ” & & & & \\
\hline
\end{tabular}

Each year the grain yield was weighed and grain as well as straw samples taken. The samples were air-dried and stored at this moisture for analysis.

\section{Field experiments}

The straw samples were taken from experiments performed with spring wheat at the South-West Finland Experimental Station and the SouthPohjanmaa Experimental Station, Ylistaro, with barley at the Central- 
Pohjanmaa, Kainuu and Karjala Experimental Stations and with oats at the South-Pohjanmaa Experimental Station. Both spring wheat experiments were on clay soil, the barley experiments on mull, Carex peat and fine sand and the oat experiment on silt soil.

The experimental design is reported in detail by SYVÄLAHTI and KORKMAN (1978). The treatments included a non-fertilized control plus four treatments fertilized each year with a usual NPK fertilizer. Different mixtures of elements were applied to three of them at the beginning of the experiment. The compounds and the application rates were the same as for plot pairs.

The plot yields were weighed and grain as well as straw samples taken every year. The samples were treated as the samples from plot pairs.

\section{Analysis}

The straw samples were analyzed at the research laboratory of Kemira Co. in Oulu by methods which are reported in detail by SAARI and PAASO (1980). The contents of ash, phosphorus, potassium, calcium, magnesium, manganese, copper, zinc, boron, molybdenum, selenium and cadmium were determined in the straw material. Cobalt, chromium, nickel and lead were determined in a more limited material.

The grain samples from the field experiments were analyzed at the same laboratory using the same methods. However, the grain samples of the plot pairs were analyzed at the Agricultural Research Centre employing slightly different methods which are reported in detail by JAAKKOLA and VOGT (1978) and VOGT and JAAKKOLA (1978). The cadmium and selenium contents were determined in Oulu.

\section{Results and discussion}

The mean and the range of contents in spring wheat grain and straw harvested from the plot pairs are presented in Table 1 . The grain yield in that particular material also given in Table 1 shows that the crop grew normally. However, as can be seen from the wide range of yield results, very poor growth occurred in some cases as well as rather satisfactory growth in others.

The samples taken for this study from the whole material of the plot pairs were satisfactorily representative when compared with the results on grain yield and mineral contents in grain (cf. JAAKKOLA and VOGT 1978, VOGT and JAAKKOLA 1978).

Among the elements determined the contents of potassium, calcium, boron, cadmium, cobalt, chromium and lead were clearly higher in the straw than in the grain. The opposite holds true most clearly with phosphorus and zinc. The variation of many contents was greater in the straw material than in the grain.

Barley straw (Table 2) did not differ very clearly from that of wheat. The 
Table 1. Grain yield and the contents of mineral elements in spring wheat grain and straw, in 1974-76.

\begin{tabular}{|c|c|c|c|c|c|}
\hline & \multicolumn{5}{|c|}{ Spring wheat } \\
\hline & \multicolumn{3}{|c|}{ Grain } & \multicolumn{2}{|c|}{ Straw } \\
\hline & mean & & ange & mean & range \\
\hline & \multicolumn{5}{|c|}{6 plots $\times 3$ years } \\
\hline Grain yield, kg/ha (15 \% moist.) & 3210 & \multicolumn{2}{|c|}{$460-4450$} & & \multirow[b]{2}{*}{$0.3-1.8$} \\
\hline Phosphorus (P), g/kg D.M. & 3.78 & 2.6 & -4.8 & 0.83 & \\
\hline Potassium (K), g/kg D.M. & 4.1 & 3.4 & -4.9 & 11.6 & $6.2-17$ \\
\hline Calcium (Ca), g/kg D.M. & 0.37 & 0.2 & -0.6 & 2.09 & $1.2-3.3$ \\
\hline Magnesium (Mg), g/kg D.M. & 1.29 & 1.1 & -1.7 & 0.98 & $0.6-1.3$ \\
\hline Manganese (Mn), mg/kg D.M. & 31 & 14 & -50 & 25 & $7-65$ \\
\hline Copper (Cu), mg/kg D.M. & 2.5 & 0.6 & -4.8 & 2.5 & $1.6-4.7$ \\
\hline Zinc $(\mathrm{Zn}), \mathrm{mg} / \mathrm{kg}$ D.M. & 28 & 10 & -62 & 10 & $3.5-26$ \\
\hline Boron (B), mg/kg D.M. & 1.3 & 0.6 & -2.5 & 3.3 & $1.9-6.0$ \\
\hline Molybdenum (Mo), mg/kg D.M. & 0.26 & 0.05 & -0.7 & 0.56 & $0.1-1.5$ \\
\hline Selenium (Se), mg/kg D.M. & 0.00 & 0.00 & -0.00 & 0.00 & $0.00-0.02$ \\
\hline \multirow[t]{2}{*}{ Cadmium (Cd), mg/kg D.M. } & 0.07 & 0.02 & -0.15 & 0.17 & $0.09-0.35$ \\
\hline & \multicolumn{5}{|c|}{3 plots $\times 3$ years } \\
\hline Cobalt (Co), mg/kg D.M. & 0.01 & 0.00 & $5-0.03$ & 0.07 & $0.01-0.2$ \\
\hline Chromium (Cr), mg/kg D.M. & 0.08 & 0.03 & -0.3 & 0.22 & $0.08-0.6$ \\
\hline Nickel (Ni), mg/kg D.M. & 0.19 & 0.04 & -0.51 & 0.20 & $0.02-2.0$ \\
\hline Lead $(\mathrm{Pb}), \mathrm{mg} / \mathrm{kg}$ D.M. & 0.19 & 0.07 & -0.40 & 1.1 & $0.5-2.0$ \\
\hline
\end{tabular}

Table 2. Grain yield and the contents of mineral elements in barley grain and straw, in 1974-76.

\begin{tabular}{|c|c|c|c|c|}
\hline & \multicolumn{4}{|c|}{ Barley } \\
\hline & \multicolumn{2}{|r|}{ Grain } & \multicolumn{2}{|c|}{ Straw } \\
\hline & mean & range & mean & range \\
\hline & \multicolumn{4}{|c|}{26 plots $\times 3$ years } \\
\hline Grain yield, kg/ha ( $15 \%$ moist.) & 2690 & $420-4520$ & & \\
\hline Phosphorus (P), g/kg D.M. & 3.81 & $1.8-5.2$ & 1.44 & $0.2-3.2$ \\
\hline Potassium (K), g/kg D.M. & 5.9 & $4.0-7.6$ & 17.8 & $4.1-29$ \\
\hline Calcium (Ca), g/kg D.M. & 0.43 & $0.3-0.8$ & 3.33 & $2.1-7.4$ \\
\hline Magnesium (Mg), g/kg D.M. & 1.14 & $0.9-1.4$ & 0.95 & $0.3-3.5$ \\
\hline Manganese (Mn), mg/kg D.M. & 31 & $9-100$ & 147 & $20-830$ \\
\hline Copper (Cu), mg/kg D.M. & 4.4 & $1.1-8.0$ & 4.1 & $1.5-11$ \\
\hline Zinc $(\mathrm{Zn}), \mathrm{mg} / \mathrm{kg}$ D.M. & 32 & $17-55$ & 24 & $4.7-67$ \\
\hline Boron (B), mg/kg D.M. & 1.0 & $0.3-3.1$ & 4.0 & $2.3-14$ \\
\hline Molybdenum (Mo), mg/kg D.M. & 0.20 & $0.03-0.9$ & 0.31 & $0.1-2.0$ \\
\hline Selenium (Se), mg/kg D.M. & 0.00 & $0.00-0.05$ & 0.01 & $0.00-0.07$ \\
\hline \multirow[t]{2}{*}{ Cadmium (Cd), mg/kg D.M. } & 0.03 & $0.00-0.40$ & 0.12 & $0.04-\quad 0.45$ \\
\hline & \multicolumn{4}{|c|}{5 plots $\times 3$ years } \\
\hline Cobalt (Co), mg/kg D.M. & 0.02 & $0.0-0.1$ & 0.15 & $0.01-0.3$ \\
\hline Chromium (Cr), mg/kg D.M. & 0.09 & $0.03-0.3$ & 0.24 & $0.1-0.9$ \\
\hline Nickel (Ni), mg/kg D.M. & 0.07 & $0.03-$ & 0.21 & $0.1-0.5$ \\
\hline Lead $(\mathrm{Pb}), \mathrm{mg} / \mathrm{kg}$ D.M. & 0.31 & $0.06-0.84$ & 1.3 & $0.7-3.0$ \\
\hline
\end{tabular}


Table 3. Grain yield and the contents of mineral elements in oat grain and straw, in 1974-76.

\begin{tabular}{|c|c|c|c|c|}
\hline & \multicolumn{4}{|c|}{ Oats } \\
\hline & \multicolumn{2}{|r|}{ Grain } & \multicolumn{2}{|c|}{ Straw } \\
\hline & mean & range & mean & range \\
\hline & \multicolumn{4}{|c|}{9 plots $\times 3$ years } \\
\hline Grain yield, $\mathrm{kg} / \mathrm{ha} \mathrm{(15} \%$ moist.) & 3240 & $1170-6290$ & & \\
\hline Phosphorus (P), g/kg D.M. & 3.54 & $2.1-4.4$ & 1.48 & $0.15-\quad 3.9$ \\
\hline Potassium (K), g/kg D.M. & 5.0 & $3.8-7.2$ & 20.5 & $8-32$ \\
\hline Calcium (Ca), g/kg D.M. & 0.66 & $0.4-1.0$ & 2.31 & $1.3-5.1$ \\
\hline Magnesium (Mg), g/kg D.M. & 1.24 & $0.9-1.5$ & 1.46 & $0.7-2.6$ \\
\hline Manganese $(\mathrm{Mn}), \mathrm{mg} / \mathrm{kg}$ D.M. & 78 & $30-190$ & 191 & $20-560$ \\
\hline Copper $(\mathrm{Cu}), \mathrm{mg} / \mathrm{kg}$ D.M. & 3.0 & $0.2-5.6$ & 3.9 & $1.5-7$ \\
\hline Zinc $(\mathrm{Zn}), \mathrm{mg} / \mathrm{kg}$ D.M. & 40 & $26-63$ & 40 & $8.7-94$ \\
\hline Boron (B), mg/kg D.M. & 1.0 & $0.6-2.5$ & 3.1 & $1.7-7.3$ \\
\hline Molybdenum (Mo), mg/kg D.M. & 0.35 & $0.1-0.6$ & 0.56 & $0.1-1.2$ \\
\hline Selenium (Se), mg/kg D.M. & 0.00 & $0.00-0.02$ & 0.01 & $0.00-0.04$ \\
\hline Cadmium (Cd), mg/kg D.M. & 0.10 & $0.00-0.55$ & 0.14 & $0.04-0.35$ \\
\hline
\end{tabular}

most pronounced differences were the higher contents of boron and especially manganese in barley straw. In addition, the range was often wider in this larger material.

Oat straw (Table 3) was rather similar to that of barley. Although the content of manganese in oat grain was higher than in barley grain, no such difference could be found in straw.

The contents of potassium, calcium and magnesium in barley and oat straw published by JOKINEN (1979) fall rather well within the range of the present material. However, some lower calcium contents were recorded by JOKINEN (1979). The contents of these elements in wheat, barley and oats reported from Australia (MULHOLLAND et al. 1974, PEARCE et al. 1979) and from the USA (MUGWIRA 1980) did not deviate markedly from the present data either. The phosphorus contents published by these Australian and American authors were rather similar to those in this material. The phosphorus contents in wheat and barley straw and grain in a German experiment (SCHMID 1977) were rather low in comparison with the present material.

The contents of boron, copper, manganese, molybdenum and zinc in spring wheat, barley and oats have been published by SIKORA (1974) in Poland. These contents fell within the range of the present material. However, the mean contents of manganese in barley and oat straw were clearly lower as were the manganese contents of barley straw published by MUGWIRA (1980) in the USA. The zinc contents in wheat and barley published in Germany by SCHMID (1977) were well within the range of the present material, however, the copper contents tended to be slightly higher in the German study.

Table 4 shows the contents of various elements in straw ash. They have been calculated by dividing the contents in dry matter by the content of ash in dry matter. Thus these contents may not in every case represent the actual composition of straw ash when burned normally. The ash content varied 
Table 4. Contents of mineral elements in cereal straw ash.

\begin{tabular}{|c|c|c|c|c|c|c|c|}
\hline & \multicolumn{2}{|c|}{ Spring wheat } & \multicolumn{3}{|c|}{ Barley } & \multicolumn{2}{|c|}{ Oats } \\
\hline No. of samples & \multicolumn{2}{|c|}{18} & \multicolumn{3}{|c|}{78} & \multicolumn{2}{|c|}{27} \\
\hline Ash content, \% D.M. & 6.0 & $3.0-10.4$ & 6.7 & 3.2 & $2-\quad 11.1$ & 7.0 & $2.7-$ \\
\hline Phosphorus, g/kg & 15.3 & $5-39$ & 25.7 & 4 & -69 & 22.7 & $3-50$ \\
\hline Potassium, g/kg & 226 & $87-390$ & 301 & $36-$ & -424 & 300 & $180-440$ \\
\hline Calcium, g/kg & 43 & $15-94$ & 58 & $5-$ & -124 & 36 & $19-75$ \\
\hline Mangnesium, g/kg & 19.1 & $11-33$ & 17.5 & $12-$ & -82 & 21.4 & $14-31$ \\
\hline Maganese, mg/kg & 400 & $190-680$ & 2590 & $230-$ & -7830 & 3480 & $370-1370$ \\
\hline Copper, mg/kg & 49 & $25-129$ & 74 & 14 & -190 & 62 & $28-192$ \\
\hline Zinc, mg/kg & 170 & $80-260$ & 440 & $80-$ & -1470 & 560 & $160-1100$ \\
\hline Boron, $\mathrm{mg} / \mathrm{kg}$ & 67 & $25-144$ & 72 & $30-$ & -249 & 48 & $19-136$ \\
\hline Molybdenum, mg/kg & 12 & $1-33$ & 5.8 & 1 & -48 & 7.4 & $1.4-14$ \\
\hline Selenium, $\mathrm{mg} / \mathrm{kg}$ & 0.03 & $0.0-0.3$ & 0.2 & 0 & $-\quad 1.5$ & 0.1 & $0-1.4$ \\
\hline Cadmium, mg/kg & 3.2 & $1.2-10.1$ & 2.2 & 0.6 & 9.0 & 2.2 & $0.5-\quad 5.3$ \\
\hline No. of samples & \multicolumn{2}{|c|}{9} & \multicolumn{3}{|c|}{9} & & \\
\hline Cobalt, $\mathrm{mg} / \mathrm{kg}$ & 1.6 & $0.2-\quad 5.2$ & 2.8 & $0.3-$ & -6.5 & & \\
\hline Chromium, mg/kg & 4.6 & $1.0-15.5$ & 4.3 & 1.5 & -10.8 & & \\
\hline Nickel, mg/kg & 3.5 & $0.5-11.4$ & 4.0 & 2.4 & $\vdash \quad 6.3$ & & \\
\hline Lead, mg/kg & 22 & $8-52$ & 27 & $10-$ & -71 & & \\
\hline
\end{tabular}

Table 5. Increase of cereal grain yield (15\% moisture) and mineral contents in grain and straw D.M., due to the application of those minerals.

\begin{tabular}{|c|c|c|c|c|c|c|c|}
\hline & & \multicolumn{2}{|c|}{ Spring wheat } & \multicolumn{2}{|c|}{ Barley } & \multicolumn{2}{|c|}{ Oats } \\
\hline & & Grain & Straw & Grain & Straw & Grain & Straw \\
\hline & & & & & & & \\
\hline \multirow[t]{2}{*}{ Grain yield, kg/ha } & lst year & 10 & - & 210 & - & 190 & - \\
\hline & 3 years in average & -30 & - & 150 & - & 200 & - \\
\hline \multirow[t]{2}{*}{ Magnesium, g/kg } & lst year & 0.01 & -0.02 & 0.01 & 0.05 & 0.03 & -0.03 \\
\hline & 3 years in average & -0.02 & 0.01 & 0.00 & 0.00 & 0.03 & 0.00 \\
\hline \multirow[t]{2}{*}{ Manganese, $\mathrm{mg} / \mathrm{kg}$} & lst year & 2 & 1 & 0 & 19 & 2 & 22 \\
\hline & 3 years in average & 0 & 0 & 0 & 0 & 0 & 10 \\
\hline \multirow[t]{2}{*}{ Copper, mg/kg } & lst year & 0.1 & 0.2 & 0.6 & 0.8 & 0.4 & 0.2 \\
\hline & 3 years in average & 0.2 & 0.1 & 0.5 & 0.5 & 0.4 & 0.2 \\
\hline \multirow[t]{2}{*}{ Zinc, mg/kg } & lst year & 0.9 & 0.1 & 0.6 & 1.6 & 2.1 & 4.2 \\
\hline & 3 years in average & 0.3 & 0.4 & -0.3 & 0.0 & 1.4 & 1.9 \\
\hline \multirow[t]{2}{*}{ Boron, mg/kg } & lst year & 0.1 & 0.2 & 0.2 & 1.0 & 0.1 & 1.1 \\
\hline & 3 years in average & 0.1 & 0.5 & 0.1 & 0.6 & 0.0 & 0.6 \\
\hline \multirow{2}{*}{ Molybdenum, mg $/ \mathrm{kg}$} & lst year & 0.06 & 0.15 & 0.00 & 0.07 & 0.05 & 0.03 \\
\hline & 3 years in average & 0.04 & 0.25 & 0.02 & 0.03 & 0.04 & 0.14 \\
\hline \multirow[t]{2}{*}{ Selenium, $\mathrm{mg} / \mathrm{kg}$} & lst year & 0.010 & 0.002 & 0.044 & 0.032 & 0.063 & 0.036 \\
\hline & 3 years in average & 0.004 & 0.002 & 0.016 & 0.010 & 0.025 & 0.016 \\
\hline \multirow[t]{2}{*}{ Cadmium, mg $/ \mathrm{kg}$} & lst year & - & 0.022 & - & 0.052 & - & 0.097 \\
\hline & 3 years in average & - & 0.001 & - & 0.025 & - & 0.041 \\
\hline
\end{tabular}


widely as did the contents of various elements in it. The most abundant element was potassium. Its content varied between 3.6 and 44 per cent. Returning the ash of burned straw to the soil has to be regarded as a rather important measure in maintaining soil potassium fertility.

The increase in the contents of most elements due to their application at the beginning was very small (Table 5 ). In this respect the present results agree quite well with those of SIKORA (1974), who studied the effect of boron, copper, manganese, molybdenum and zinc application on their content in grain and straw. The contents of manganese, boron and molybdenum were usually increased more in straw than in grain which is in accordance with SIKORA's (1974) results.

In Table 5 the first year averages as well as means of all three years are presented in order to show if the effect in the first year was greater than during the other two. There is some evidence that this really was true in some cases. For example, manganese, zinc, boron, selenium and cadmium in barley and oat straw seem to have responded in that way. On the contrary, the molybdenum content increased more in the later years.

Table 6. Grain yield of spring wheat (15\% moisture) and contents of mineral elements in grain and straw in different treaments, mean of two experiments in three years and range in individual experiments and years.

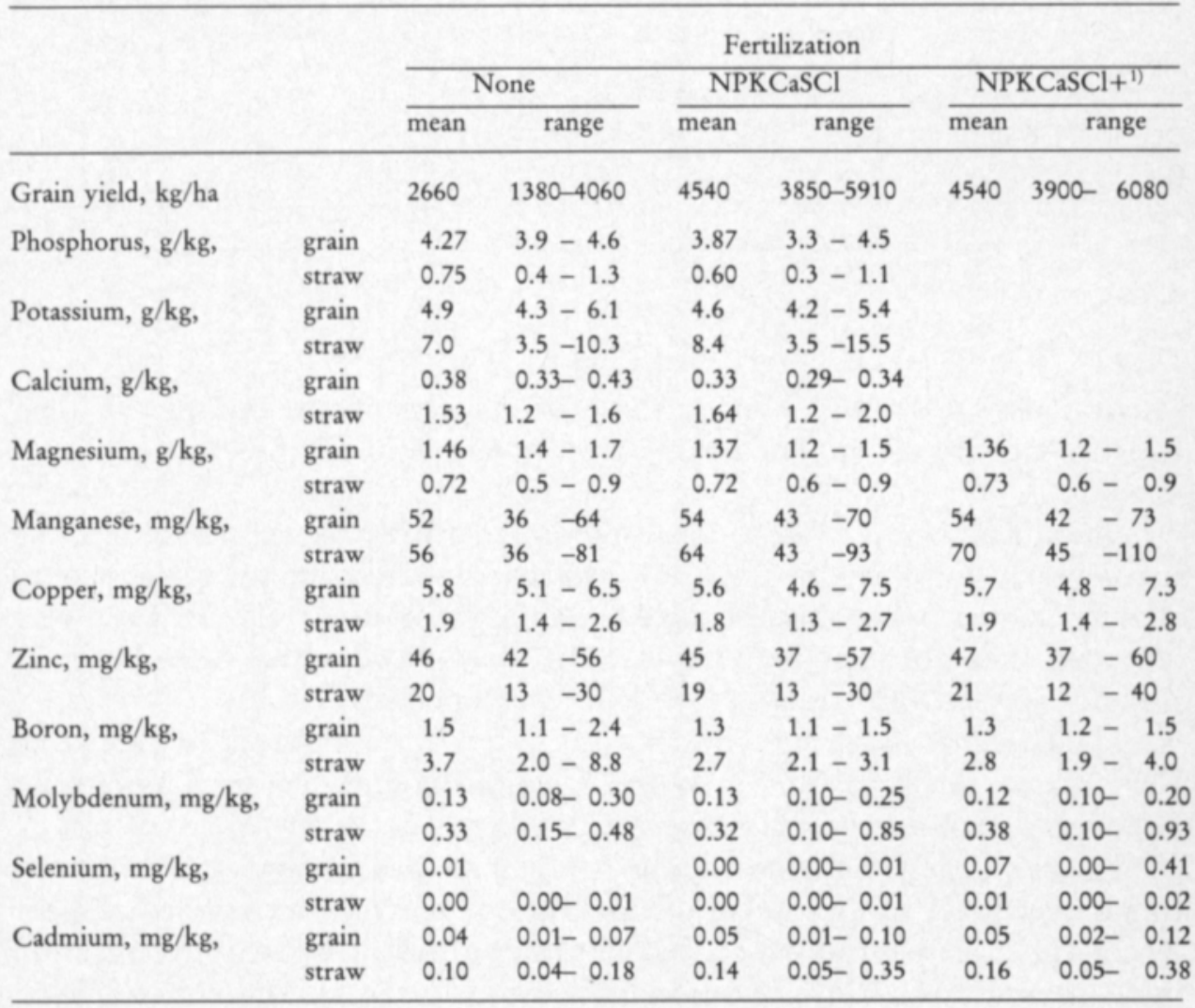

1) the element whose content is given in this column was included in the first year's fertilization. 
Table 7. Grain yield of barley (15\% moisture) and contents of mineral elements in grain and straw D.M. with varying fertilization, mean of three experiments and three years and range in individual experiments and years.

\begin{tabular}{|c|c|c|c|c|c|c|c|c|c|}
\hline & & \multicolumn{8}{|c|}{ Fertilization } \\
\hline & & \multicolumn{2}{|c|}{ None } & \multicolumn{3}{|c|}{ NPKCaSCl } & \multicolumn{3}{|c|}{$\mathrm{NPKCaSCl}+{ }^{1)}$} \\
\hline & & mean & range & mean & & nge & mean & & inge \\
\hline Grain yield, kg/ha & & 1900 & $1480-2930$ & 2730 & $1890-3$ & -3900 & 2850 & 1910 & -4530 \\
\hline \multirow[t]{2}{*}{ Phosphorus, g/kg, } & grain & 3.99 & $3.5-4.8$ & 3.98 & $3.5-$ & -5.0 & & & \\
\hline & straw & 1.32 & $0.6-2.5$ & 1.18 & $0.3-$ & -2.3 & & & \\
\hline \multirow[t]{2}{*}{ Potassium, g/kg, } & grain & 6.3 & $4.8-7.4$ & 6.6 & $4.7-$ & -7.6 & & & \\
\hline & straw & 17.0 & $5.3-27$ & 19.6 & $4.3-$ & -29 & & & \\
\hline \multirow[t]{2}{*}{ Calcium, g/kg, } & grain & 0.42 & $0.35-0.48$ & 0.46 & $0.37-$ & -0.57 & & & \\
\hline & straw & 2.87 & $2.1 \quad 4.0$ & 3.23 & $2.2-$ & -4.3 & & & \\
\hline \multirow[t]{2}{*}{ Magnesium, $\mathrm{g} / \mathrm{kg}$, } & grain & 1.25 & $1.0-1.6$ & 1.21 & $0.9-$ & -1.6 & 1.23 & $0.9-$ & -1.5 \\
\hline & straw & 0.72 & $0.5-0.9$ & 0.72 & $0.6-$ & -0.9 & 0.73 & $0.6-$ & -0.9 \\
\hline \multirow[t]{2}{*}{ Manganese, $\mathrm{mg} / \mathrm{kg}$, } & grain & 31 & $16-51$ & 33 & $22-$ & -47 & 31 & $20-$ & -45 \\
\hline & straw & 140 & $20-340$ & 100 & $40-1$ & -170 & 100 & $30-$ & -190 \\
\hline \multirow[t]{2}{*}{ Copper, mg/kg, } & grain & 7.6 & $5.9-9.3$ & 7.4 & $5.6-$ & -9.0 & 8.2 & $5.5-$ & -11.0 \\
\hline & straw & 4.4 & $2.7-5.8$ & 3.8 & $2.2-$ & -5.1 & 4.2 & $2.3-$ & -5.6 \\
\hline \multirow[t]{2}{*}{ Zinc, $\mathrm{mg} / \mathrm{kg}$, } & grain & 36 & $26-46$ & 41 & $32-$ & -49 & 38 & $31-$ & -49 \\
\hline & straw & 29 & $21-39$ & 27 & $20-$ & -39 & 26 & $17-$ & -36 \\
\hline \multirow[t]{2}{*}{ Boron, $\mathrm{mg} / \mathrm{kg}$, } & grain & 0.9 & $0.5-1.5$ & 1.0 & $0.5-$ & -1.3 & 1.2 & $1.0-$ & -1.5 \\
\hline & straw & 4.3 & $3.1-6.2$ & 3.9 & $2.9-$ & -5.7 & 5.1 & $3.6-$ & -7.5 \\
\hline \multirow[t]{2}{*}{ Molybdenum, mg $/ \mathrm{kg}$, } & grain & 0.08 & $0.03-0.25$ & 0.08 & 0.03 & 0.28 & 0.10 & $0.03-$ & 0.25 \\
\hline & straw & 0.19 & $0.10-0.48$ & 0.17 & 0.10 & -0.48 & 0.36 & 0.10 & 0.80 \\
\hline \multirow[t]{2}{*}{ Selenium, mg $/ \mathrm{kg}$, } & grain & 0.01 & $0.00-0.02$ & 0.00 & 0.00 & 0.01 & 0.05 & 0.00 & 0.18 \\
\hline & straw & 0.00 & $0.00-0.02$ & 0.00 & 0.00 & 0.02 & 0.02 & 0.00 & 0.05 \\
\hline \multirow[t]{2}{*}{ Cadmium, $\mathrm{mg} / \mathrm{kg}$, } & grain & 0.02 & $0.01-0.08$ & 0.02 & $0.01-$ & 0.03 & 0.02 & $0.01-$ & 0.05 \\
\hline & straw & 0.10 & $0.04-0.18$ & 0.14 & 0.05 & 0.35 & 0.16 & 0.05 & 0.38 \\
\hline
\end{tabular}

1) the element whose content is given in this column was included in the first year's fertilization.

In Tables 6-8 only two or three of the five treatments in the field experiments are given. The results are the means of all three experimental years.

The spring wheat straw did not respond markedly to the omission of the usual yearly fertilization (Table 6). However, some contents tended to be slightly higher when not fertilized, although opposite effects were also recorded. The boron content in straw increased most clearly when fertilizer was not applied. The response of grain was much smaller.

The contents in spring wheat straw could not be increased by applying elements to the soil. Not even the selenium content in straw increased although its content in grain rose very clearly.

The manganese content of barley straw increased somewhat when omitting the fertilizer application (Table 7). The content was generally of a higher level than that in spring wheat straw. Other differences due to fertilization were insignificant. The application of elements to the soil did not in general result in elevated contents in straw or grain. However, the boron, molyb- 
Table 8. Grain yield of oats (15\% moisture) and contents of mineral elements in grain and straw D.M. with varying fertilization, mean and range in three years of one experiment.

\begin{tabular}{|c|c|c|c|c|c|c|c|c|c|}
\hline & & \multicolumn{8}{|c|}{ Fertilization } \\
\hline & & \multicolumn{3}{|c|}{ None } & \multicolumn{2}{|c|}{ NPKCaSCl } & \multicolumn{3}{|c|}{ NPKCaSCl+1) } \\
\hline & & mean & & range & mean & range & mean & & ange \\
\hline \multicolumn{2}{|l|}{ Grain yield, kg/ha } & 4450 & & $30-5240$ & 5900 & $5210-6270$ & 6120 & 5630 & 6600 \\
\hline \multirow[t]{2}{*}{ Phosphorus, $\mathrm{g} / \mathrm{kg}$, } & grain & 4.04 & & $0-4.2$ & 3.83 & $3.6-4.2$ & & & \\
\hline & straw & 0.94 & & $5-1.6$ & 0.77 & $0.3-1.6$ & & & \\
\hline \multirow[t]{2}{*}{ Potassium, g/kg, } & grain & 5.1 & & $6-6.1$ & 5.0 & $4.2-5.7$ & & & \\
\hline & straw & 20.3 & 18.5 & $5-22.5$ & 22.3 & $19.8-24.5$ & & & \\
\hline \multirow[t]{2}{*}{ Calcium, g/kg, } & grain & 0.73 & & $7-0.8$ & 0.77 & $0.7-0.8$ & & & \\
\hline & straw & 2.76 & & $5-3.0$ & 3.21 & $2.9-3.6$ & & & \\
\hline \multirow[t]{2}{*}{ Magnesium, g/kg, } & grain & 1.42 & & $4-1.5$ & 1.37 & $1.3-1.4$ & 1.42 & 1.4 & -1.5 \\
\hline & straw & 1.20 & & $1-1.4$ & 1.29 & $1.2-1.5$ & 1.29 & 1.1 & -1.5 \\
\hline \multirow[t]{2}{*}{ Manganese, $\mathrm{mg} / \mathrm{kg}$, } & grain & 67 & 65 & -68 & 67 & $66-68$ & 71 & 68 & -74 \\
\hline & straw & 88 & 77 & -94 & 96 & $83-104$ & 102 & 85 & -118 \\
\hline \multirow[t]{2}{*}{ Copper, mg/kg, } & grain & 6.3 & & $9-6.8$ & 6.5 & $6.3-7.0$ & 6.6 & 6.0 & -7.0 \\
\hline & straw & 4.0 & & $7-5.5$ & 4.1 & $2.6-6.2$ & 4.2 & 2.7 & -6.2 \\
\hline \multirow[t]{2}{*}{ Zinc, $\mathrm{mg} / \mathrm{kg}$, } & grain & 47 & 42 & -51 & 47 & $43-52$ & 48 & 44 & -55 \\
\hline & straw & 21 & 15 & -31 & 17 & $11-28$ & 20 & 12. & -32 \\
\hline \multirow[t]{2}{*}{ Boron, $\mathrm{mg} / \mathrm{kg}$, } & grain & 1.4 & & $1-1.7$ & 1.6 & $1.3-1.7$ & 1.8 & 1.5 & -2.1 \\
\hline & straw & 5.2 & & $9-6.3$ & 7.2 & $4.6-11.9$ & 8.0 & 5.4 & $-\quad 12.8$ \\
\hline \multirow[t]{2}{*}{ Molybdenum, $\mathrm{mg} / \mathrm{kg}$, } & grain & 0.14 & & $10-0.18$ & 0.12 & $0.10-0.15$ & 0.15 & 0.13 & $3-0.17$ \\
\hline & straw & 0.43 & & $38-0.55$ & 0.22 & $0.10-0.43$ & 0.39 & 0.20 & 0.68 \\
\hline \multirow[t]{2}{*}{ Selenium, $\mathrm{mg} / \mathrm{kg}$, } & grain & 0.01 & & & 0.00 & $0.00-0.01$ & 0.03 & 0.01 & 0.05 \\
\hline & straw & 0.01 & & $00-0.02$ & 0.01 & $0.00-0.02$ & 0.01 & 0.00 & 0.03 \\
\hline \multirow[t]{2}{*}{ Cadmium, mg $/ \mathrm{kg}$, } & grain & 0.01 & & & 0.01 & & 0.01 & 0.01 & 0.02 \\
\hline & straw & 0.05 & & $05-0.06$ & 0.05 & $0.04-0.07$ & 0.07 & 0.05 & 0.08 \\
\hline
\end{tabular}

1) the element whose content is given in this column was included in the first year's fertilization.

denum and selenium contents in straw did increase. Again, the selenium content in grain responded more than that in straw.

The fertilization of oats seemed to increase the boron content in straw somewhat (Table 8). Barley and wheat reacted in the opposite way. The fertilization of oats also caused a decrease in the molybdenum content in straw, an effect which could not be recognized in wheat and barley. Application of elements to the soil was an ineffective way of increasing their contents in straw the only exception being molybdenum the application of which raised its content in straw to the same level as in the non-fertilized treatment. 


\title{
References
}

JAAKKOLA, A. \& VOGT, P. 1978. The effect of mineral elements added to Finnish soils on the mineral contents of cereal, potato, and hay crop. I. Calcium, magnesium, phosphorus, potassium, copper, iron, manganese, sodium and zinc. Acta Agric. Scand., Suppl. 20: 53-68.

JOKINEN, R. 1979. The effect of magnesium, potassium and nitrogen fertilizers on the contents and ratios of nutrients in spring cereals and grassland crops. Ann. Agric. Fenn. 18: 188-202.

MUGWIRA, L. M. 1980. Preliminary studies on Triticale Triticosecale, wheat Triticum-Aestivum, barley Hordeum-Vulgare and rye Secale-Cereale responses to lime and nitrogen. Commun Soil Sci. Plant. Anal. 11 (6): 587-604.

MULLHOLLAND, J. G., COOMBE, J. B. \& McMANUS, W. R. 1974. Intake and liveweight response of sheep fed three ground and pelleted cereal straws. Aust. J. Exp. Agric. Anim. Husb. 14: 449-453.

PEARCE, G. R., BEARD, J. \& HILLIARD, E. P. 1979. Variability in the chemical composition of cereal straws and in vitro digestibility with and without sodium hydroxide treatments. Aust. J. Exp. Agric. Anim. Husb. 19: 350-353.

SAARI, E. \& PAASO, A. 1980. Mineral element composition of Finnish foods. II. Analytical methods. Acta Agric. Scand., Suppl. 22: 15-25.

SCHMID, R. 1977. Phosphat-, Kupfer- und Zinkgehalt in Boden und Pflanze nach 6jähriger Klärschlammanwendung in einem Feldversuch. Landwirtschaft. Forsch. 30, 2: 125-129.

SIKORA, H. 1974. The influence of fertilizing with microelements on the content of $\mathrm{B}, \mathrm{Cu}, \mathrm{Mn}, \mathrm{Mo}, \mathrm{Zn}$ in the soils and plants. Pamietnik Pulawski 59: 101-131.

SYVÄLAHTI, J. \& KORKMAN, J. 1978. The effect of applied mineral elements on the mineral content and yield of cereals and potato in Finland. Acta Agric. Scand., Suppl. 20: 80-89.

VOGT, P. \& JAAKKOLA, A. 1978. The effect of mineral elements added to Finnish soils on the mineral contents of cereal, potato and hay crops. II. Aluminium, boron, molybdenum, strontium, chromium, cobalt, lead and nickel. Acta Agric. Scand., Suppl. 20: 69-79.

Ms received December 3, 1982.

\section{SELOSTUS}

\section{Olkien kivennäisainepitoisuus}

\author{
Antti Jaakkola \\ MTTK, Maanviljelyskemian ja -fysiikan osasto, 31600 JOKIOINEN
}

Jorma Syvälahti

Kemira Oy, Malminkatu 30, 00100 HELSINKI 10

\section{Esko Saari}

Kemira Oy, Oulun tutkimuslaitos, PL 171, 90101 OULU 10

Vuosina 1974-76 tehtyyn maaperän ja viljelykasvien kivennäisainetutkimukseen kuuluneilta kuudelta kevätvehnä, kahdeltakymmeneltäkuudelta ohraa ja yhdeksältä kauraa kasvaneelta normaalisti lannoitetulta ruudulta otettiin kolmena peräkkäisenä vuonna olki- ja jyvänäytteet. Ruudut sijaitsivat eri puolilla Suomea. Näytteistä määritettiin $\mathrm{P}, \mathrm{K}, \mathrm{Ca}, \mathrm{Mg}, \mathrm{Mn}, \mathrm{Cu}, \mathrm{Zn}, \mathrm{B}, \mathrm{Mo}, \mathrm{Se}$ ja Cd sekä osasta näytteitä lisäksi $\mathrm{Co}, \mathrm{Cr}, \mathrm{Ni}$ ja $\mathrm{Pb}$. Pitoisuudet eivät poikenneet mainittavasti ulkomailla todetuista huolimatta hyvin erilaisista kasvuolosuhteista.

Myös kuudesta kenttäkokeesta, joissa selvitettiin maan pintaan levitettyjen kivennäisaineiden sekä NKP-lannoituksen vaikutusta jyväsatoon ja jyvien kivennäisainepitoisuuteen, otettiin olkinäytteet. NPKlannoitus ei vaikuttanut kivennäisainekoostumukseen merkittävästi. Myöskään näiden aineiden välitön lisääminen maahan ei juuri vaikuttanut. Vaikka seleenilisäys nosti jyvien seleenipitoisuutta selvästi, olkien pitoisuus kohosi vain vähän. 